\title{
CHEMICAL CONTENT IN THE SEMBEQ TRADITIONAL RITUALS OF THE LOMBOK COMMUNITY
}

\author{
Yayuk Andayani ${ }^{*}$, Burhanuddin, Aliefman Hakim, I Nyoman Loka, Muti'ah \\ Chemistry Education Study Program FTTE, University of Mataram, Mataram, Indonesia \\ *Email: yayukmtr@unram.ac.id
}

Acceped: August 27 2021. Approved: Sept 01 2021. Published: Sept 032021

\begin{abstract}
This study aims to identify and describe the chemical content in the sembeq traditional rituals, especially in the medicinal purpose of the Lombok community. Qualitative approach research with a phenomenological approach is used in focusing on data collecting of the Sembeq tradition. Data on indigenous knowledge of the community was obtained through interviews with Belians, who were the key informants. Data in the form of narration were analyzed descriptively. The results showed that in the Sembeq tradition, which is used for medicinal purposes, the main ingredients are betel leaf, areca nut, and fine lime. Chemical content relevant to the sembeq tradition includes secondary metabolites, mixtures, chemical reactions, bases, solution $\mathrm{pH}$, and surface area.
\end{abstract}

Keywords: Sembeq, chemical, indigenous, metabolite secondary

\section{INTRODUCTION}

The island of Lombok cannot be taken from beliefs and traditions that are considered to have religious values, mutual respect, and hospitality, which are unique characteristics of people's lives with socio-religious traits [1]. Sembeq is an unwritten tradition passed down from generation to generation and is still believed and valid in some Lombok people. Sembeq is a symbolic tradition of the Lombok people that has a deep meaning [2] and, in practice, is accompanied by prayer or mantra pronounce certain people can only perform that.

Although sembeq was initially used for medicinal purposes made by a belian/traditional healer, sembeq became expanded in various traditional Lombok rituals such as pedaq api rituals, peresean, bau nyale, weddings, and reception for welcoming traditional guests.

The Sembeq tradition includes a complex of knowledge, belief, art, morals, law, and everything that is a habit of society. Cultural characteristics in ethnoscience include values, attitudes, and knowledge which are important elements in developing student character. It is what lies behind the development of an ethnoscience approach in the learning process [3], and to increase the relevance of science learning, a breakthrough in curriculum and pedagogy is needed besides learning science theory and facts

Ethnoscience integration in learning, especially chemistry, in the classroom and the laboratory, is still not widely done [4]. Difficulty in identifying relevant chemical concepts in ethnoscience is a problem faced by many teachers. Identification of the chemical content of the Sembeq tradition will be beneficial for realizing meaningful learning because this tradition has been embedded in the daily life of the Lombok people. This study aims to identify and describe the chemical content in the Sembeq traditional ritual of the Lombok community. The research results are expected to contribute to the development of ethnoscience-based chemistry teaching materials that can be used in learning in schools.

\section{RESEARCH METHODS}

This study uses a qualitative method with a phenomenological approach. In general, qualitative research uses descriptive data in the form of words or expressions, including actions [5] observed in the Sembeq tradition in Lombok society. Data on the symbolic meaning of the sembeq tradition were obtained through interviews with key informants, namely Belian that experts in performing the sembeq ritual. The data were analyzed qualitatively through the stages of data reduction, data presentation in narrative form, and concluding [6].

\section{RESULTS AND DISCUSSION Sembeq Tradition}

The sembeq tradition is a heritage to the community from generation to generation from their ancestors. Initially, sembeq was used for medicinal purposes, usually used to cure headaches and fever, but what developed in the sembeq community was also used in other traditional rituals. A similar opinion was expressed by Iptika [7] that people believe that betel nut can strengthen teeth, eliminate bad breath, and cure toothache and nourish the body. It happens because the hydrolysis of lime on arecoline produces arcaidine, which is a central nervous stimulant. When mixed with betel leaf, it can produce mild euphoria, which gives addictive properties and a sense of pleasure when chewed.

The sembeq process is closely related to mamaq activities, namely nginang or betel nut activities such as Javanese tradition, but there are slight differences between the two. Sembeq is practiced using prayers or mantras, so sembeq can 
only be done by certain people with special abilities such as belian or traditional healers. While mamaq activities can be done by anyone and are believed to cure canker sores, relieve toothache and strengthen teeth.

The sembeq tradition with the aim of treatment is carried out through the preparation, implementation, and closing ceremony stages. The preparatory stage is begun by the patient's family to be treated the andang-andang to be brought to the belian's house as a condition for carrying out the ritual. Andang-andang generally contains the main ingredients for sembeq, rice, and volunteer money. The implementation stage begins with Belian preparing offerings that have been brought by the patient, followed by making sembeq, with the main ingredients being betel leaf, areca nut, and fine lime. The betel used is green betel with the condition that the sketch of the leaf part must meet between one side and the other. But this also depends on the disease to be treated. Next, Belian chews/memamaq a mixture of betel, areca nut, and fine lime while saying a prayer or a mantra. Commonly used tools such as mortar. After everything is prepared to smooth the mixture instead of chewing. The ingredients are given to the patient's family and explain how to use it, namely by rubbing the sembeq mixture on the sick part of the patient, for example, on the head for headaches. The closing stage is when Belian has finished sembeq ceremony, and the patient's family can leave the Belian house.

The sembeq ritual process consists of a series of actions carried out from preparation to closing stage. It is in accordance with the opinion of Koentjaraningrat [8] as well as Purba and Pasaribu [9] that rituals are a series of actions arranged by the prevailing customs in society to fulfill the needs of teachings or cultural and spiritual values that have been passed down from generation to generation from their ancestors.

\section{Chemical Content in the Sembeq tradition}

Identification of chemical content in the sembeq tradition is focused on the main ingredients, namely betel, areca nut, and lime, while the process used in sembeq is the chewing process, mixing betel, areca nut, and fine lime.

\section{Betel (Piper betel)}

The use of betel in the context of ethnoscience (original knowledge of the community) is believed to strengthen teeth, relieve toothache, cure canker sores and reduce fever [10]. This original knowledge of the community is in line with the results of research that proves that betel has broad bioactivity, such as activity as antimicrobial [11], antioxidant [12], antiinflammatory and analgesic [13], anti-cancer, anticholesterol, analgesic, immunomodulatory and hepatoprotective [13] [14]

The broad spectrum of bioactivity of betel nut is directly or indirectly related to the content of secondary metabolites. Prakash et al. [15] found as many as 32 compounds that have been identified from betel leaf, and the main compounds they contain are eugenol and acetyleuge-nol. Eugenol functions as an anti-alphatoxin, phenolic is widely associated with antioxidant activity [16]. Thus, the chemical content relevant to the use of betel in the sembeq tradition is organic compounds, especially secondary metabolites.

\section{Areca nut (Areca catechu)}

The ethnoscience context of areca nut in the sembeq tradition is intended to give red color and a spicy taste used for treatment. Several studies have reported the bioactivity of Areca catechu, such as antimicrobial [17], anti-inflammatory [18], and anti-migraine [19]. This bioactivity results from secondary metabolites in areca nuts such as alkaloids, flavonoids, tannins, saponins, and polyphenols. Thus the chemical content that can be identified from areca nut is secondary metabolite compounds.

\section{Fine lime}

The ethnoscience context of whiting used in the sembeq tradition has benefits for periodontal tissue health. Fine lime is made by heating or burning limestone (calcium carbonate, $\mathrm{CaCO}_{3}$ ), which is then cooled with the addition of water to produce whiting (calcium oxide, $\mathrm{CaO}$ ) and gas (carbon dioxide, $\mathrm{CO}_{2}$ ). Betel lime or $\mathrm{CaO}$ is a reactive material with water and will form $\mathrm{Ca}(\mathrm{OH})_{2}$. Calcium hydroxide, which has a high $\mathrm{pH}$, will cause the oral cavity to be alkaline and produce a type of reactive oxygen in the form of hydroxyl radical $(\mathrm{OH} \bullet)$.

This radical can damage the DNA oxidation system of mucosa cells of betel doers and accelerate plaque buildup on their teeth. Chemical contents in whiting or fine lime include base, $\mathrm{pH}$ of the solution, and chemical reaction equation.

\section{The process of chewing a mixture of betel, areca nut, and fine lime}

The ethnoscience context in the chewing process carried out by Belian aims to smooth the mixture of betel leaf, areca nut, and lime so that it is easy to use for treatment. Chewing betel leaf and areca nut can trigger saliva production, which helps the process of mixing ingredients. Saliva contains various proteins and minerals that are good for maintaining strong teeth and preventing gum disease. Chewing betel nut can produce reddish-brown saliva. This color is due to the presence of tannin and catechin compounds in the sap of the leaves and twigs of the gambier plant and anthocyanins in green betel leaves [20].

Based on this explanation, the chemical content contained in the process of chewing a 
mixture of betel, areca nut, and lime includes mixture, chemical reaction, surface area, and secondary metabolite compounds. The existence of a variety of chemical content that can be identified from the sembeq tradition of the Lombok people is expected to help teachers, who find it challenging to integrate culture in learning activities. According to Gondwe \& Longnecker [21], combining scientific knowledge in schools with indigenous scientific knowledge in the community encourages students to be more concerned about their surrounding environment. Moreover, according to Ameyaw [22], the integration of local wisdom/indigenous science does not reduce the understanding of scientific concepts but can increase the meaning of these concepts.

\section{CONCLUSION}

The Sembeq tradition of the Lombok people, which is used for medicinal purposes, uses the main ingredients of betel leaf, areca nut, and fine lime. Making sembeq is by chewing or smoothing with mortar of a mixture of ingredients carried out by a traditional healer or Belian. The chemical content in the sembeq tradition includes secondary metabolites, mixtures, chemical reactions, bases, $\mathrm{pH}$ of the solution, and surface area.

\section{ACKNOWLEDGMENTS}

DIPA Mataram University funded this research, Ministry of Education, Culture, Research and Technology of the Republic of Indonesia, through a PNBP research scheme for the 2021 fiscal year.

\section{REFERENCES}

[1] Ria, K \& Budi, N. (2014). Adat Istiadat Nusa Tenggara Barat. Bandung: Sarana Panca Karya Nusa.

[2] Ratmaja, L.(2018) Jampi-Jampi Batur Sasak. Lombok Timur: Puskabud.

[3] Ibe, E., \& Nwosu, A.A. (2017). Effects of Ethnoscience and traditional laboratory practical on science process skills acquisition of secondary school biology students in Nigeria. British Journal of Multidisciplinary and Advanced Studies, 1(1), 35-46.

[4] Andayani, Y., Yunita, A. S., Saprizal, H. (2021). Pendekatan Etnosains Dalam Pelajaran Kimia Untuk Pembentukan Karakter Siswa: Tanggapan Guru Kimia Di NTB J. Pijar MIPA, 39-43

[5] Pitana, T. S.(2014). Teori Sosial Kritis: Metode dan Aplikasinya. Purwokerto: STAIN Press.

[6] Miles, M. B., dan Huberman, M. A. (2009). Analisis Data Kualitatif: Buku Sumber Tentang Metode-metode Baru. Jakarta: UI Press.

[7] Iptika, Amalisa. (2013). Keterkaitan Kebiasaan Kepercayaan Mengunyah sirih Pinang dengan Kesehatan gigi. departemen Antropologi FISIP Universitas Airlangga

[8] Koentjaraningrat (2005). Pengantar Antropologi I. Jakarta: Rineka Cipta
[9] Purba, M. dan Pasaribu, B. (2005). Musik Populer: Buku Pelajaran Kesenian Nusantara. Jakarta: Lembaga Pendidikan Seni Nusantara.

[10] Silalahi, M., Nisyawati, Walujo, E.B. \& Supriatna, J. (2015). Local knowledge of medicinal plants in sub-ethnic Batak Simalungun of North Suma-tra, Indonesia. Biodiversitas 16(1): 44-54.

[11] Hossain, M.F., Anwar, M., Akhtar, S., \& Numan, S.M. (2017). Uses impact of betel leaf (Piper betle L.) on public health. Science Journal of Public Health 5(6): 408-410

[12] Makopo, S., Yeoh, T.W., Ruslam, F.A.C., Arifin, K.T., \& Yusof, Y.A.M. (2013). Comparative effect of Piper betle, Chlorella vulgaris and tocotrienol-rich fraction on antioxidant enzymes activity in cellular ageing of human diploid fibroblasts. $B M C$ Complementary and Alternative Medicine 13:101-110

[13] Alam, B., Akter, F., Parvin, N., Pia, R.S., Akter, S., Chowdhury, J., Jahan, K.S.E., \& Haque, E. (2013). Antioxidant, analgesic and anti inflam-matory activities of the methanolic extract of Piper betle leaves. Avicenna Journal of Phytomedicine 3(2):112125

[14] Silalahi, M (2019) Manfaat Dan Bioaktivitas Piper Betle L. Cendekia Journal of Pharmacy, Vol. 3, No. 2: 137-146

[15] Prakash, B., Shukla, R., Singh, P., Kumar, A., Mishra, P.K., \& Dubey, N.K. (2010). Efficacy of chemically characterized Piper betle L. essential oil against fungal and aflatoxin contamination of some edible commodities and its antioxidant activity. Intern-ational Journal of Food Microbiology 142: 114-119.

[16] Abrahim, N.N., Kanthimathi, M.S., \& AbdulAziz, A. (2012). Piper betle shows antioxidant activities, inhibits $\mathrm{MCF}-7$ cell proliferation and increases activities of catalase and superoxide dismutase. $B M C$ Complementary and Alternative Medicine 12:220

[17] Anthikat, R.R.N., Michael, A., Kinsalin, V.A., \& Ignacimuthu, S. (2014). Antifungal activity of Areca catechu L. International Journal of Pharmaceutical and Clinical Science 4(1): 1-3

[18] Lee, K.P., Sudjarwo, G.W., Kim, J.S., Dirgantara, S., Maeng, W.J., \& Hong, H. (2014). The anti-inflammatory effect of Indonesian Areca catechu leaf extract in vitro and in vivo. Nutrition Research and Practice 8(3): 267-271.

[19] Bhandare, A., Kshirsagar, A., Vyawahare, N., Sharma, P., \& Mohite, R. (2011). Evaluation of anti-migraine potential of Areca catechu to prevent nitroglycerin-induced delayed 
inflammation in rat meninges: Possible involvement of NOS inhibition. Journal of Ethnopharmacology 136 (2011) 267-270

[20] Prabhu, K. H., \& Bhute, A. S. (2012). Plant based natural dyes and mordants. A Review. J. Nat. Prod. Plant Resour, 2(6), 649-664

[21] Gondwe, M. \& Longnecker, N. (2015). Scientific and Cultural Knowledge in Intercultural Science Education. Student Perceptions of Common Ground, 117- 147.

[22] Ameyaw, Y. (2011). Environmental pedagogies that promote students understanding of integrated science (biology aspect). Journal of Education, 1 (1), 10-15fi 